Article

\title{
The Effect of Intranasal Oxytocin on Measures of Social Cognition in Schizophrenia: A Negative Report
}

Mary R. Lee ${ }^{1, *, \dagger}$, Heidi J. Wehring ${ }^{2, \dagger}$, Robert P. McMahon ${ }^{2}$, Fang Liu ${ }^{2}$, Jared Linthicum ${ }^{2}$, Robert W. Buchanan ${ }^{2}$, Gregory P. Strauss ${ }^{2}$, Leah H. Rubin ${ }^{3}$, Deanna L. Kelly ${ }^{2}$

${ }^{1}$ Section on Clinical Psychoneuroendocrinology and Neuropsychopharmacology, National Institute on Alcohol Abuse and Alcoholism, National Institutes of Health, Bethesda, MD 21228, USA

${ }^{2}$ Maryland Psychiatric Research Center, University of Maryland School of Medicine, Baltimore MD 21201, USA

${ }^{3}$ Women's Mental Health Research Program, University of Illinois at Chicago, IL 60612, USA

$\dagger$ These two authors contribute equally to this work.

*Correspondence: Mary R. Lee, Email: leemary@mail.nih.gov.

\section{ABSTRACT}

Social cognition is impaired in patients with schizophrenia and is related to functional outcome. Neither current pharmacologic treatments for psychotic symptoms nor psychosocial interventions robustly improves measures of social cognition. Given this, the development of adjunctive treatments to improve functional outcome is a rational approach to treatment research in schizophrenia. The neuropeptide oxytocin is a candidate to treat deficits in social cognition due to its prosocial as well as anxiolytic effects. We report here results from a randomized, double-blind, parallel group 3 week clinical trial with daily administration of adjunctive intranasal oxytocin (20 IU twice daily) ( $n=$ $13)$ or placebo $(n=15)$. We examined the effect of oxytocin administration on measures of 4 domains of social cognition, as well as social functioning. After 3 weeks of oxytocin/placebo dosing, there was no significant difference favoring oxytocin between treatment groups in any outcome measure. These results add to the body of literature

\section{G Open Access}

Received: 6 December 2018 Accepted: 24 December 2018

Published: 09 January 2019

Copyright (c) 2019 by the author(s). Licensee Hapres, London, United Kingdom. This is an open access article distributed under the terms and conditions of Creative Commons Attribution 4.0 International License. examining the effects of oxytocin on social cognition in schizophrenia. Further study is warranted.

KEYWORDS: oxytocin; schizophrenia; social cognition

\section{INTRODUCTION}

Social cognition includes making inferences about other people's mental state, perception of emotions from facial cues, social cue perception, and reasoning about certain types of social information; all of these are impaired in persons with schizophrenia [1]. Social cognition 
mediates the relationship between neurocognition and functional outcome in schizophrenia [2-6].

Current pharmacological treatments for symptoms of psychosis do not significantly impact social cognition. Therefore, targeting this domain with adjunctive treatments to improve functional outcome is a rational approach to treatment research in schizophrenia.

One candidate treatment in this regard is oxytocin (OT), a naturally occurring hormone, which has been associated with improving aspects of social cognition in humans, such as social bonding/positive interaction, trust, empathy, and emotional perception/memory [7,8]. Some studies have reported a positive relationship between plasma OT levels and social cognitive capacity such as prosocial behaviors or ability to perceive emotions in schizophrenia [9-15], while other studies reported no relationship between OT levels and social cognition measures [16,17]. Keri and colleagues [18] reported that schizophrenia patients exhibit a blunted OT response after trusting interaction compared to controls, suggesting a dysregulation of OT signaling in schizophrenia.

Clinical trials administering adjunctive OT to remediate symptoms and social cognition deficits have also yielded mixed outcomes [19-28]. Results from these studies overall show that OT may have some effect on negative symptoms, however our work found negative symptom improvement in inpatients only, suggesting the potential for contextual response or lack of adherence in the outpatient setting [25]. A recent meta-analysis of 12 randomized clinical trials of intranasal OT in patients with schizophrenia did not report overall improvements in social cognition or neurocognition [29]. However, a larger effect was found on high-level social cognition, such as theory of mind, compared with low-level social cognition such as social cue perception [29].

In addition, OT possesses anxiolytic, anti-stress effects [30,31], and exogenous administration may modulate anxiety symptoms and reduce fear and stress [32] in persons without schizophrenia. Although constructs separate from social cognition, it is well established that anxiety, stress, and poor social interaction are common in schizophrenia and predictive of poor functional outcomes. Therefore, studying the effects of exogenous OT administration on these symptoms would be valuable.

To this end, we studied the effect of repeated administration of OT on social cognition and social anxiety endpoints. We previously reported the results of this study with respect to the effect of repeated dosing of intranasal OT on positive and negative psychotic symptoms [25]. We explored four domains of social cognition capturing the breadth of this construct: Theory of Mind, emotion perception and recognition, attributional styles, and social knowledge. 


\section{METHODS}

The methods of this study have been outlined in detail in a previous publication [25]. Subjects: Twenty-eight participants with a diagnosis of schizophrenia or schizoaffective disorder (Structured Clinical Interview for Diagnostic and Statistical Manual of Mental Disorders (DSM-IV) Axis I Disorders, Clinical version Structured Clinical Interview for DSM-IV (SCID) [33] who were inpatients or outpatients on a stable medication regimen participated in this clinical trial. Participants were excluded if they met DSM-IV criteria for substance dependence in last 6 months or DSM-IV criteria for substance abuse in past 30 days, were pregnant or lactating, had severe medical condition, history of polydipsia/hyponatremia, clinically significant rhinitis, or cognitive impairment severe enough to preclude informed consent as assessed by the Evaluation to Sign Consent(ESC) [34]. Participants were recruited from the Maryland Psychiatric Center's Treatment Research Program and Outpatient Research Program. This study was approved by the University of Maryland and National Institute on Drug Abuse Institutional Review Boards.

Study Design/Experimental Procedures: Following a two-week lead in phase, participants were randomized to three week treatment of adjunctive intranasal OT (20IU twice daily) $(n=13)$ or matching placebo (PBO) $(n=15)$, then followed with weekly study visits. Measures of social cognition and social outcomes were performed at baseline (BL) prior to study medication initiation and at endpoint (EP).

The Brief Psychiatric Rating Scale (BPRS), the Schedule for the Assessment of Negative Symptoms (SANS), the Clinical Global Impression (CGI), and the Calgary Depression Scale for Schizophrenia (CDSS) were performed to evaluate symptoms of psychosis, negative symptoms, overall function, and depressive symptoms. Symptom measures have been reported elsewhere [25].

Primary outcomes for social measures were the Mayer-Salovay Caruso Emotional Intelligence Test (MSCEIT) [35], Managing Emotions and Understanding Emotions components and the Maryland Assessment of Social Competence (MASC) [36]. The MSCEIT, Managing Emotions and Understanding Emotions components, have been used by others in schizophrenia research [37-39] and are the only social cognitive assessments to be a part of the Measurement and Treatment Research to Improve Cognition in Schizophrenia (MATRICS) battery [40]. The MASC is a standardized evaluation that involves behavioral observation of role play tests in order to determine social competence in specific situations. In the role play test, the patient role plays for $3 \mathrm{~min}$ with a confederate who gives standardized responses. In the test, the responsibility to keep up the conversation and problem solve lies with the patient. The session is videotaped and rated for conversational content, nonverbal content and effectiveness (see Table 1). The MASC has been shown to have good discriminatory power for assessing overall social skill deficits among people with schizophrenia. Secondary outcomes included measures of 
social cognition, quality of life, and social anxiety. These are listed in Table 1 with specification of the subtype of social cognition or anxiety measured.

Data Analysis: Analysis of covariance (ANCOVA) was used to compare changes between treatment groups at study end-point (EP) for social cognition and social functioning scores, controlling for age and baseline (BL) values in each treatment group, using the model. A mixed model was used controlling for age and BL values: outcome $=$ BL primary outcome variable + age + treatment group. Since the only important difference between groups was mean age, with the OT group being significantly older ( $44.74 \pm 11.74 v s .35 .07 \pm 8.21$ ), age was used as a covariate in all analyses.

Table 1. Means (SD) for Measures of Social Cognition and Social Anxiety.

\begin{tabular}{|c|c|c|c|c|c|c|}
\hline \multicolumn{7}{|c|}{ Primary Social Cognition Assessments } \\
\hline Assessment & Description of Test & BL OT & EP OT & BL PBO & EP PBO & Test \\
\hline \multicolumn{7}{|l|}{ MSCEIT [35] } \\
\hline $\begin{array}{l}\text { Managing Emotions } \\
\text { Branch Score }\end{array}$ & $\begin{array}{l}\text { emotional intelligence; } \\
\text { ability to be open to } \\
\text { feelings, modulation of } \\
\text { emotions in self/others }\end{array}$ & $\begin{array}{l}87.1 \\
(10.0)\end{array}$ & $\begin{array}{l}85.1 \\
(9.4)\end{array}$ & $\begin{array}{l}80.7 \\
(7.2)\end{array}$ & $\begin{array}{l}80.7 \\
(8.9)\end{array}$ & $\begin{array}{l}F=1.64 \\
d_{\mathrm{f}}=1,23 \\
p=0.21\end{array}$ \\
\hline $\begin{array}{l}\text { Understanding } \\
\text { Emotions Branch } \\
\text { Score }\end{array}$ & $\begin{array}{l}\text { emotional intelligence; } \\
\text { ability to understand } \\
\text { emotional information }\end{array}$ & $\begin{array}{l}82.2 \\
(12.4)\end{array}$ & $\begin{array}{l}76.7 \\
(9.2)\end{array}$ & $\begin{array}{l}77.9 \\
(9.8)\end{array}$ & $\begin{array}{l}84.3 \\
(10.4)\end{array}$ & $\begin{array}{l}F=1.70 \\
d_{\mathrm{f}}=1,23 \\
p=0.21\end{array}$ \\
\hline \multicolumn{7}{|l|}{ MASC [36] } \\
\hline $\begin{array}{l}\text { Conversational } \\
\text { Content }\end{array}$ & $\begin{array}{l}\text { interpersonal social } \\
\text { skill assessment; assess } \\
\text { conversation }\end{array}$ & $\begin{array}{l}3.13 \\
(0.75)\end{array}$ & $\begin{array}{l}3.13 \\
(0.76)\end{array}$ & $\begin{array}{l}3.1 \\
(0.71)\end{array}$ & $\begin{array}{l}3.13 \\
(0.77)\end{array}$ & $\begin{array}{l}F=1.38 \\
d_{\mathrm{f}}=1,24 \\
p=0.25\end{array}$ \\
\hline Non-Verbal Content & $\begin{array}{l}\text { interpersonal social } \\
\text { skill assessment; assess } \\
\text { non-verbal } \\
\text { performance }\end{array}$ & $\begin{array}{l}3.13 \\
(0.65)\end{array}$ & $\begin{array}{l}2.92 \\
(0.83)\end{array}$ & $\begin{array}{l}2.93 \\
(0.75)\end{array}$ & $\begin{array}{l}2.98 \\
(0.88)\end{array}$ & $\begin{array}{l}F=1.66 \\
d_{\mathrm{f}}=1,24 \\
p=0.21\end{array}$ \\
\hline Effectiveness & $\begin{array}{l}\text { Interpersonal social } \\
\text { skill assessment; asses } \\
\text { effectiveness } \\
\text { performance }\end{array}$ & $\begin{array}{l}3.03 \\
(0.62)\end{array}$ & $\begin{array}{l}2.97 \\
(0.79)\end{array}$ & $\begin{array}{l}2.98 \\
(0.73)\end{array}$ & $\begin{array}{l}3.13 \\
(0.80)\end{array}$ & $\begin{array}{l}F=4.86 \\
d_{\mathrm{f}}=1,24 ; \\
p=0.037\end{array}$ \\
\hline
\end{tabular}


Table 1. Cont.

\begin{tabular}{|c|c|c|c|c|c|c|}
\hline \multicolumn{7}{|c|}{ Secondary Social Cognition and Functional Outcome Measures } \\
\hline Assessments & $\begin{array}{l}\text { Description of } \\
\text { Measure }\end{array}$ & BL OT & EP OT & BL PBO & EP PBO & Test \\
\hline $\begin{array}{l}\text { Facial Emotion } \\
\text { Identification } \\
\text { Test(FEIT) [41] }\end{array}$ & $\begin{array}{l}\text { emotional } \\
\text { perception }\end{array}$ & $\begin{array}{l}12.0 \\
(2.1)\end{array}$ & $\begin{array}{l}11.92 \\
(2.22)\end{array}$ & $\begin{array}{l}11.36 \\
(2.65)\end{array}$ & $\begin{array}{l}11.15 \\
(1.95)\end{array}$ & $\begin{array}{l}F=0.07 \\
d_{\mathrm{f}}=1,22 ; \\
p=0.80\end{array}$ \\
\hline $\begin{array}{l}\text { Profile of Nonverbal } \\
\text { Sensitivity (Half-PONS) } \\
{[42]}\end{array}$ & $\begin{array}{l}\text { social perception } \\
\text { through nonverbal } \\
\text { cues }\end{array}$ & $\begin{array}{l}73.8 \\
(11)\end{array}$ & $\begin{array}{l}69.0 \\
(11.5)\end{array}$ & $\begin{array}{l}72.2 \\
(11.7)\end{array}$ & $\begin{array}{l}76.7 \\
(8.5)\end{array}$ & $\begin{array}{l}F=3.08 \\
d_{\mathrm{f}}=1,17 \\
p=0.10\end{array}$ \\
\hline $\begin{array}{l}\text { Personal and Social } \\
\text { Performance } \\
\text { Scale(PSP) [43] }\end{array}$ & $\begin{array}{l}\text { socially useful } \\
\text { activities, personal and } \\
\text { social relationships, } \\
\text { self-care and } \\
\text { disturbing and } \\
\text { aggressive behaviors to } \\
\text { assess functioning }\end{array}$ & $\begin{array}{l}48.2 \\
(8.5)\end{array}$ & $\begin{array}{l}50.2 \\
(7.7)\end{array}$ & $\begin{array}{l}50.2 \\
(8.8)\end{array}$ & $\begin{array}{l}52.1 \\
(10.1)\end{array}$ & $\begin{array}{l}F=0.06 \\
d_{\mathrm{f}}=1,24 \\
p=0.81\end{array}$ \\
\hline $\begin{array}{l}\text { Attributional Style } \\
\text { Questionnaire(ASQ) } \\
{[44]}\end{array}$ & $\begin{array}{l}\text { event valence(positive } \\
\text { or negative) and cause } \\
\text { of event (internal or } \\
\text { external) }\end{array}$ & $\begin{array}{l}16.3 \\
(2.5)\end{array}$ & $\begin{array}{l}16.5 \\
(2.2)\end{array}$ & $\begin{array}{l}15.7 \\
(1.7)\end{array}$ & $\begin{array}{l}15.4 \\
(2.1)\end{array}$ & $\begin{array}{l}F=0.60, \\
d_{\mathrm{f}}=1,21 ; \\
p=0.445\end{array}$ \\
\hline $\begin{array}{l}\text { Quality of Life } \\
\text { Enjoyment and } \\
\text { Satisfaction } \\
\text { Questionnaire } \\
\text { (QLESQ) [45] }\end{array}$ & $\begin{array}{l}\text { enjoyment and } \\
\text { satisfaction in various } \\
\text { areas of daily } \\
\text { functioning }\end{array}$ & $\begin{array}{l}41.7 \\
(6.4)\end{array}$ & $\begin{array}{l}40.31 \\
(7.5)\end{array}$ & $\begin{array}{l}34.8 \\
(10.8)\end{array}$ & $\begin{array}{l}34.0 \\
(10.3)\end{array}$ & $\begin{array}{l}F=0.2 \\
d_{\mathrm{f}}=1,24 ; \\
p=0.66\end{array}$ \\
\hline $\begin{array}{l}\text { Reading the Mind in } \\
\text { the Eyes (RMET) [46] } \\
\% \text { accuracy }\end{array}$ & theory of mind & $\begin{array}{l}60.7 \\
(17.1)\end{array}$ & $\begin{array}{c}56.2 \\
(17.7)\end{array}$ & $\begin{array}{l}57.3 \\
(10.6)\end{array}$ & $\begin{array}{l}54.4 \\
(12.2)\end{array}$ & $\begin{array}{l}F=0.11 \\
d_{\mathrm{f}}=1,23 \\
p=0.74\end{array}$ \\
\hline \multicolumn{7}{|c|}{ Social Anxiety Assessments } \\
\hline Assessment & $\begin{array}{l}\text { Description of } \\
\text { Measure }\end{array}$ & BL OT & EP OT & BL PBO & EP PBO & Test \\
\hline $\begin{array}{l}\text { Social Interaction } \\
\text { Anxiety Scale(SIAS) } \\
{[47]}\end{array}$ & $\begin{array}{l}\text { general fear and } \\
\text { attitudes of social } \\
\text { situations }\end{array}$ & $\begin{array}{l}30.1 \\
(14.4)\end{array}$ & $\begin{array}{l}26.4 \\
(12.1)\end{array}$ & $\begin{array}{l}33.9 \\
(17.8)\end{array}$ & $\begin{array}{l}26.1 \\
(14.2)\end{array}$ & $\begin{array}{l}F=0.23 \\
d_{\mathrm{f}}=1,24 ; \\
p=0.64\end{array}$ \\
\hline $\begin{array}{l}\text { Brief Fear of Negative } \\
\text { Evaluation(BFNE) [48] }\end{array}$ & $\begin{array}{l}\text { concerns of being } \\
\text { negatively evaluated } \\
\text { by others }\end{array}$ & $\begin{array}{l}18.8 \\
(7.4)\end{array}$ & $\begin{array}{l}17.4 \\
(7.2)\end{array}$ & $\begin{array}{l}22.3 \\
(8.6)\end{array}$ & $\begin{array}{l}19.6 \\
(7.2)\end{array}$ & $\begin{array}{l}F=0.04 \\
d_{\mathrm{f}}=1,24 \\
p=0.85\end{array}$ \\
\hline
\end{tabular}




\section{RESULTS}

Participants were primarily male (69\% oxytocin (OT) and 73\% placebo (PBO)) and white (77\% and 53\%, respectively). Baseline demographics, including sex, race, education, marital status, schizophrenia symptoms, smoking status, and placement (inpatient or outpatient) were similar between the two groups, with the exception of age (44.74 (11.74) years $v s$. 35.07 (8.21) years respectively). Age was used as a covariate in all analyses. No significant treatment effects were found between the OT-treated and PBO groups at the end of study for any primary social cognitive (Mayer-Salovay Caruso Emotional Intelligence Test (MSCEIT), Maryland Assessment of Social Competence (MASC)) or secondary social cognition or anxiety outcomes. Primary and secondary social cognition outcomes as well as social anxiety outcomes are listed in Table 1. A significant change in the study favoring placebo was found for the MASC effectiveness measure ( $F=4.86, d_{\mathrm{f}}=1,24 ; p=0.037$ ), however, this would not survive correction for multiple testing.

\section{DISCUSSION}

No significant benefits in social cognition were found in this pilot clinical trial of 28 persons with schizophrenia treated with adjunctive intranasal oxytocin (OT) or placebo (PBO) for three weeks. These results add to the extant studies examining the use of OT for social cognitive endpoints in schizophrenia [19,20,22-24,26,27,49]. These previous studies used comparable doses of intranasal OT and had similar sample sizes, but focused on narrower measures of social cognition. The two largest trials ( $N=52$ and $N=55$ ), used comparable doses of OT (40 IU twice daily for 6 weeks or 24 IU twice daily for 12 weeks). In one trial, OT was an adjunct to social cognitive therapy [20] and in the other it was an adjunct to antipsychotic treatment [27]. In both of these clinical trials, OT failed to improve social cognition measures [20,27].

The absence of an effect of OT on primary and secondary outcome measures may have been due to several factors including small sample size and a study population that was not selected for any particular level of social deficits. In addition, a three week study may have been inadequate to effect a change in these outcomes. However, the results of this study are important as they add to the extant body of literature examining the effects of intranasal OT on social cognition given the results of a recent meta-analysis suggesting that OT may not broadly improve overall social cognition or neurocognition, rather, it may improve more specific aspects of deficits in schizophrenia [29].

Single dose studies of intranasal OT have reported improvements in some aspects of social cognition [20,50-52]. However studies with repeated dosing of OT to patients with schizophrenia have not yielded robust improvements in social cognition [53,54]. Indeed, we did not see an effect in higher level social cognition as has been suggested in a 
meta-analysis of randomized controlled trials of intranasal OT in schizophrenia [29]. The effect size reported in the meta-analysis was 0.2 (Hedges g). Our power calculations were based on the MSCEIT and MASC. For our sample size enrolled we estimated in this pilot study a priori that with power $=0.80$ the effect size would need to be 0.84 to show group differences. For an effect size of 0.2 , power was $<0.80$ and we were not powered to find between group treatment effects with this sample size. The calculated sample size for this power and effect size was 14 per group so we were not underpowered to detect an effect A recent imaging study suggested that OT may improve social cognition in schizophrenia by reducing amygdala activation during emotionally-valenced social decision making [55]. Notwithstanding this, our findings added to the meta-analysis findings are highly suggestive of a lack of effect on repeated administration of OT in schizophrenia for robust improvements alone on any domain of social cognition. However, strategies to use OT with cognitive behavioral therapy or social skills training may be a more effective strategy [49]. These could be effective given the context dependent effect of OT [56] as well as the advances recently in cognitive behavioral therapy and other social skills strategies for schizophrenia [57]. Lastly, the optimal dosing of intranasal OT remains unknown. Endogenous OT receptor expression is altered in some brain regions such as the temporal cortex [58]. Repeated receptor activation often leads to receptor desensitization and or reduced membrane expression [59]. Therefore, the quantity delivered and its frequency may alter OT signaling in individuals with SZ who already have altered OT receptor expression in certain brain regions. More research needs to be done on how these variables affect behavioral outcomes.

\section{AUTHOR CONTRIBUTIONS}

MRL and HJW contributed equally to this work. They wrote the initial draft and managed the data analysis. RPM served as the statistician and helped in the design and analysis of the study. FL participated in the study design and the management and analysis of data. JL was the study coordinator and assisted in the design, implementation and dissemination. RWB was a coinvestigator that helped in the study design, implementation and writing. GPS and LHR were coinvestigators that helped with the study procedures and data analysis. DLK and MRL served as the study co-principal investigators and designed the study. DLK supervised all study activities and participated in the design, implementation and data analysis. All authors contributed to the paper writing and reviewed the final version. 


\section{FUNDING}

This study was funded by a National Institute on Drug Abuse (NIDA) contract (N01-DA-5-9909; Kelly PI) the Maryland Psychiatric Research Center, University of Maryland.

\section{ACKNOWLEDGEMENTS}

We would like to thank the staff and faculty of the Treatment Research Program for their assistance with subject recruitment and study assessments.

\section{CONFLICTS OF INTEREST}

DLK has served as an advisor for XOMA and Lundbeck. RWB served on the advisory boards for Amgen, Astellas, Janssen Pharmaceuticals, Inc., NuPathe, Inc., Pfizer, Roche, and Takeda. He also serves as a DSMB member for Pfizer and Otsuka. RPM served as a consultant for Amgen. Other authors have no conflicts of interest to report.

\section{REFERENCES}

1. Green MF, Horan WP, Lee J. Social cognition in schizophrenia. Nat Rev Neurosci. 2015;16(10):620-31.

2. Couture SM, Roberts DL, Penn DL, Cather C, Otto MW, Goff D. Do baseline client characteristics predict the therapeutic alliance in the treatment of schizophrenia? J Nerv Mental Dis. 2006;194(1):10-4.

3. Addington J, Saeedi H, Addington D. Influence of social perception and social knowledge on cognitive and social functioning in early psychosis. $\mathrm{Br} \mathrm{J}$ Psychiatry 2006;189:373-8.

4. Brekke J, Kay DD, Lee KS, Green MF. Biosocial pathways to functional outcome in schizophrenia. Schizophr Res. 2005;80(2-3):213-25.

5. Sergi MJ, Rassovsky Y, Nuechterlein KH, Green MF. Social perception as a mediator of the influence of early visual processing on functional status in schizophrenia. Am J Psychiatry. 2006;163(3):448-54.

6. Vauth R, Rusch N, Wirtz M, Corrigan PW. Does social cognition influence the relation between neurocognitive deficits and vocational functioning in schizophrenia? Psychiatry Res. 2004;128(2):155-65.

7. Churchland PS, Winkielman P. Modulating social behavior with oxytocin: how does it work? What does it mean? Hormones Behav. 2012;61(3):392-9.

8. Meyer-Lindenberg A, Domes G, Kirsch P, Heinrichs M. Oxytocin and vasopressin in the human brain: social neuropeptides for translational medicine. Nat Rev Neurosci. 2011;12(9):524-38.

9. Goldman M, Marlow-O'Connor M, Torres I, Carter CS. Diminished plasma oxytocin in schizophrenic patients with neuroendocrine dysfunction and emotional deficits. Schizophr Res. 2008;98(1-3):247-55.

10. Rubin LH, Carter CS, Drogos L, Pournajafi-Nazarloo H, Sweeney JA, Maki PM. Peripheral oxytocin is associated with reduced symptom severity in schizophrenia. Schizophr Res. 2010;124(1-3):13-21. 
11. Rubin LH, Carter CS, Drogos L, Jamadar R, Pournajafi-Nazarloo H, Sweeney JA, Maki PM. Sex-specific associations between peripheral oxytocin and emotion perception in schizophrenia. Schizophr Res. 2011;130(1-3):266-70.

12. Walss-Bass C, Fernandes JM, Roberts DL, Service H, Velligan D. Differential correlations between plasma oxytocin and social cognitive capacity and bias in schizophrenia. Schizophr Res. 2013;147(2-3):387-92.

13. Strauss GP, Keller WR, Koenig JI, Gold JM, Frost KH, Buchanan RW. Plasma oxytocin levels predict social cue recognition in individuals with schizophrenia. Schizophr Res. 2015;162(1-3):47-51.

14. Strauss GP, Keller WR, Koenig JI, Sullivan SK, Gold JM, Buchanan RW. Endogenous oxytocin levels are associated with the perception of emotion in dynamic body expressions in schizophrenia. Schizophr Res. 2015;162(1-3):52-56.

15. Brown EC, Tas C, Kuzu D, Esen-Danaci A, Roelofs K, Brune M. Social approach and avoidance behaviour for negative emotions is modulated by endogenous oxytocin and paranoia in schizophrenia. Psychiatry Res. 2014;219(3):436-42.

16. Rubin LH, Carter CS, Bishop JR, Pournajafi-Nazarloo H, Drogos LL, Hill SK, et al. Reduced levels of vasopressin and reduced behavioral modulation of oxytocin in psychotic disorders. Schizophr Bull. 2014;40(6):1374-84.

17. Rubin LH, Carter CS, Bishop JR, Pournajafi-Nazarloo H, Harris MS, Hill SK, Reilly JL, Sweeney JA. Peripheral vasopressin but not oxytocin relates to severity of acute psychosis in women with acutely-ill untreated first-episode psychosis. Schizophr Res. 2013;146(1-3):138-43.

18. Keri S, Kiss I, Kelemen O. Sharing secrets: oxytocin and trust in schizophrenia. Soc Neurosci. 2009;4(4):287-293.

19. Oya K, Matsuda Y, Matsunaga S, Kishi T, Iwata N. Efficacy and safety of oxytocin augmentation therapy for schizophrenia: an updated systematic review and meta-analysis of randomized, placebo-controlled trials. Eur Arch Psychiatry Clin Neurosci. 2016;266(5):439-50. doi:10.1007/s00406-015-0634-9.

20. Cacciotti-Saija C, Langdon R, Ward PB, Hickie IB, Scott EM, Naismith SL, et al. A double-blind randomized controlled trial of oxytocin nasal spray and social cognition training for young people with early psychosis. Schizophr Bull. 2015;41(2):483-93.

21. Davis MC, Horan WP, Nurmi EL, Rizzo S, Li W, Sugar CA, Green MF. Associations between oxytocin receptor genotypes and social cognitive performance in individuals with schizophrenia. Schizophr Res. 2014;159(2-3):353-7.

22. Gibson CM, Penn DL, Smedley KL, Leserman J, Elliott T, Pedersen CA. A pilot six-week randomized controlled trial of oxytocin on social cognition and social skills in schizophrenia. Schizophr Res. Jul 2014;156(2-3):261-5.

23. Feifel D, Macdonald K, Nguyen A, Cobb P, Warlan H, Galangue B. et al. Adjunctive intranasal oxytocin reduces symptoms in schizophrenia patients. Biol Psychiatry. 2010;68(7):678-80.

24. Pedersen CA, Gibson CM, Rau SW, Salimi K, Smedley KL, Casey RL, et al. Intranasal oxytocin reduces psychotic symptoms and improves Theory of 
Mind and social perception in schizophrenia. Schizophr Res. 2011;132(1):50-3.

25. Lee MR, Wehring HJ, McMahon RP, Linthicum, J, Cascella, N, Liu, F, et al. Effects of adjunctive intranasal oxytocin on olfactory identification and clinical symptoms in schizophrenia: results from a randomized double blind placebo controlled pilot study. Schizophr Res. 2013;145(1-3):110-5.

26. Modabbernia A, Rezaei F, Salehi B, Jafarinia M, Ashrafi M, Tabrizi M, et al. Intranasal oxytocin as an adjunct to risperidone in patients with schizophrenia: an 8-week, randomized, double-blind, placebo-controlled study. CNS Drugs 2013;27(1):57-65.

27. Jarskog LF, Pedersen CA, Johnson JL, Hamer RM, Rau SW, Elliott T, Penn DL. A 12-week randomized controlled trial of twice-daily intranasal oxytocin for social cognitive deficits in people with schizophrenia. Schizophr Res. 2017;185:88-95.

28. Buchanan RW, Kelly DL, Weiner E, Gold JM, Strauss GP, Koola MM, McMahon RP, Carpenter WT. A Randomized Clinical Trial of Oxytocin or Galantamine for the Treatment of Negative Symptoms and Cognitive Impairments in People With Schizophrenia. J Clin Psychopharmacol. 2017;37(4):394-400.

29. Bürkner P-C, Williams DR, Simmons TC, Woolley JD. Intranasal Oxytocin May Improve High-Level Social Cognition in Schizophrenia, But Not Social Cognition or Neurocognition in General: A Multilevel Bayesian Meta-analysis. Schizophr Bull. 2017;43(6):1291-303.

30. Heinrichs M, Baumgartner T, Kirschbaum C, Ehlert U. Social support and oxytocin interact to suppress cortisol and subjective responses to psychosocial stress. Biol Psychiatry. 2003;54(12):1389-98.

31. Uvnas-Moberg K, Petersson M. Oxytocin, a mediator of anti-stress, well-being, social interaction, growth and healing. Z Psychosom Med Psychother. 2005;51(1):57-80.

32. Acheson D, Feifel D, de Wilde S, McKinney R, Lohr J, Risbrough V. The effect of intranasal oxytocin treatment on conditioned fear extinction and recall in a healthy human sample. Psychopharmacology. 2013;229(1):199-208.

33. First MB. The DSM series and experience with DSM-IV. Psychopathology. 2002;35(2-3):67-71.

34. DeRenzo EG, Conley RR, Love R. Assessment of capacity to give consent to research participation: state-of-the-art and beyond. J Health Care Law Policy. 1998;1(1):66-87.

35. Mayer JD, Salovey P, Caruso DR, Sitarenios G. Measuring emotional intelligence with the MSCEIT V2.0. Emotion. 2003;3(1):97-105.

36. Bellack AS, Brown CH, Thomas-Lohrman S. Psychometric characteristics of role-play assessments of social skill in schizophrenia. Behav Ther. 2006;37(4):339-52.

37. Kee KS, Horan WP, Salovey P, Kern RS, Sergi MJ, Fiske AP, et al. Emotional intelligence in schizophrenia. Schizophr Res. 2009;107(1):61-8. 
38. Frajo-Apor B, Pardeller S, Kemmler G, Welte A-S, Hofer A. Emotional Intelligence deficits in schizophrenia: The impact of non-social cognition. Schizophr Res. 2016;172(1-3):131-6.

39. DeTore NR, Mueser KT, McGurk SR. What does the Managing Emotions branch of the MSCEIT add to the MATRICS consensus cognitive battery? Schizophr Res. 2018;doi:10.1016/j.schres.2018.02.018.

40. Buchanan RW, Davis M, Goff D, Green MF, Keefe RS, Leon AC, et al. A summary of the FDA-NIMH-MATRICS workshop on clinical trial design for neurocognitive drugs for schizophrenia. Schizophr Bull. 2005;31(1):5-19.

41. Kerr SL, Neale JM. Emotion perception in schizophrenia: specific deficit or further evidence of generalized poor performance? J Abnorm Psychol. 1993;102(2):312-8.

42. Ambady $\mathrm{N}$, Hallahan $\mathrm{M}$, Rosenthal R: On judging and being judged accurately in zero-acquaintance situations. J Pers Soc Psychol 1995;69:519-29

43. Morosini PL, Magliano L, Brambilla L, Ugolini S, Pioli R. Development, reliability and acceptability of a new version of the DSM-IV Social and Occupational Functioning Assessment Scale (SOFAS) to assess routine social functioning. Acta Psychiatr Scand. 2000;101(4):323-29.

44. Tennen H, Herzberger S, Nelson HF. Depressive attributional style: the role of self-esteem. J Pers. 1987;55(4):631-60.

45. Endicott J, Nee J, Harrison W, Blumenthal R. Quality of Life Enjoyment and Satisfaction Questionnaire: a new measure. Psychopharmacol Bull. 1993;29(2):321-6.

46. Baron-Cohen S, Wheelwright S, Hill J, Raste Y, Plumb I. The "Reading the Mind in the Eyes" Test revised version: a study with normal adults, and adults with Asperger syndrome or high-functioning autism. J Child Psychol Psychiatry. 2001;42(2):241-51.

47. Mattick RP, Clarke JC. Development and validation of measures of social phobia scrutiny fear and social interaction anxiety. Behav Res Ther. 1998;36(4):455-70.

48. Watson D, Friend R. Measurement of social-evaluative anxiety. J Consult Clin Psychol. 1969;33(4):448-57.

49. Davis MC, Green MF, Lee J, Horan WP, Senturk D, Clarke AD, Marder SR. Oxytocin-augmented social cognitive skills training in schizophrenia. Neuropsychopharmacology. 2014;39(9):2070-2077.

50. Davis MC, Lee J, Horan WP, Clarke AD, McGee MR, Green MF, Marder SR. Effects of single dose intranasal oxytocin on social cognition in schizophrenia. Schizophr Res. 2013;147(2-3):393-7.

51. Abu-Akel A, Fischer-Shofty M, Levkovitz Y, Decety J, Shamay-Tsoory S. The role of oxytocin in empathy to the pain of conflictual out-group members among patients with schizophrenia. Psychol Med. 2014;44(16):3523-32.

52. Fischer-Shofty M, Shamay-Tsoory S, Levkovitz Y. Characterization of the effects of oxytocin on fear recognition in patients with schizophrenia and in healthy controls. Front Neurosci. 2013;7(127). doi:10.3389/fnins.2013.00127. 
53. Burkner PC, Williams DR, Simmons TC, Woolley JD. Intranasal Oxytocin May Improve High-Level Social Cognition in Schizophrenia, But Not Social Cognition or Neurocognition in General: A Multilevel Bayesian Meta-analysis. Schizophr bull. 2017;43(6):1291-303.

54. Williams DR, Burkner PC. Effects of intranasal oxytocin on symptoms of schizophrenia: A multivariate Bayesian meta-analysis. Psychoneuroendocrinology. 2017;75:141-51.

55. Michalopoulou P, Wigton R, Averbeck B, Shergill S. M67. The Neural Effects of Oxytocin on Social Decision-Making in Schizophrenia: An fMRI Study. Schizophr Bull. 2017;43(Suppl 1): S234.

56. Bartz JA, Zaki J, Bolger N, Ochsner KN. Social effects of oxytocin in humans: context and person matter. Trends Cogn Sci. 2011;15(7):301-9.

57. Granholm E, Holden J, Worley M. Improvement in Negative Symptoms and Functioning in Cognitive-Behavioral Social Skills Training for Schizophrenia: Mediation by Defeatist Performance Attitudes and Asocial Beliefs. Schizophr Bull. 2018 Apr 6;44(3):653-61. doi:10.1093/schbul/sbx099.

58. Uhrig S, Hirth N, Broccoli L, von Wilmsdorff M, Bauer M, Sommer C, et al. Reduced oxytocin receptor gene expression and binding sites in different brain regions in schizophrenia: A post-mortem study. Schizophr Res. 2016;177(1-3):59-66.

59. Jurek B, Neumann ID. The Oxytocin Receptor: From Intracellular Signaling to Behavior. Physiol. Rev. 2018;98(3):1805-908.

How to cite this article:

Lee MR, Wehring HJ, McMahon RP, Liu F, Linthicum J, Buchanan RW, et al. The Effect of Intranasal Oxytocin on Measures of Social Cognition in Schizophrenia: A Negative Report. J Psychiatry Brain Sci. 2019;4:e190001. https://doi.org/10.20900/jpbs.20190001 